\title{
Filsafat Politik Al-Farabi
}

\author{
Abdullah Said \\ UIN Sunan Kalijaga Yogyakarta \\ abdullah_said70@yahoo.co.id
}

\begin{abstract}
The concept of a democratic state has become a concept that has been echoed by many countries over the past few centuries, the concept of a democratic state seems to be a concept of a state that is ideal for many countries that apply it, while in reality, many problems exist within the democratic system itself, a democratic system that determines the most votes in determining a leader without seeing the quality of prospective leaders becomes one of the weak points in the democratic system. This research will discuss how the ideal state concept in al-Farabi's thinking. This research is a library research, the method used in this research is descriptive analysis and qualitative methods. Al-Farabi put forward the theory of al-Madinah al-Fädilah to harmonize between religion and philosophy. The concept of state contained in al-Farabi's theory is modeled after the form and nature of Rasullullah's leadership as an Apostle and caliph. Besides that, the concept of an ideal state in its ideas was influenced by the thoughts of Plato and Aristotle, especially the idea of humans as social beings, besides that al-Farabi was also influenced by many socio-political events during the Abbasid caliphate. Political opposition, insurrection, political stability and insecure security are the main factors that emerge.
\end{abstract}

Keywords: Al-Farabi, Philosophy, Politic

Abstrak: Konsep negara demokrasi menjadi sebuah konsep yang di dengungkan oleh banyak negara selama beberapa abad terakhir ini, konsep negara demokrasi seakan-akan menjadi sebuah konsep negara yang sangat ideal bagi banyak negara yang menerapkannya, Sedang pada kenyataannya, banyak 
problematika yang terdapat dalam sistem demokrasi itu sendiri, sistem demokrasi yang menentukan suara terbanyak dalam penentuan seorang pemimpin tanpa melihat kualitas calon pemimpin menjadi salah satu titik kelemahan dalam sistem demokrasi. Penelitian ini akan membahas bagaimana konsep Negara ideal dalam pemikiran al-Farabi. Penelitian ini merupakan penelitian kepustakaan, Metode yang digunakan dalam penelitian ini metode deskriptif analisis dan bersifat kualitatif. Al-Farabi mengemukakan teori al-Madīnah al-Fạ̣̈ilah untuk mengharmonikan antara agama dan filsafat. Konsep kenegaraan yang terdapat dalam teori al-Farabi ini banyak mencontoh bentuk dan hakikat kepimpinan Rasullullah Saw sebagai seorang Rasul dan khalifah. Disamping itu juga, Konsep negara ideal dalam gagasanya dipengaruhi oleh pemikiran Plato dan juga Aristoteles, khususnya gagasan tentang manusia sebagai makhluk sosial, selain itu juga al-Farabi juga dipengaruhi banyaknya peristiwa sosial politik pada masa khalifah Abbasyiah. Pertentangan politik, pemberontakan, stabilitas politik dan keamanan yang tidak terjamin menjadi faktor utama gagasan tersebut muncul.

Kata kunci: Al-Farabi, Filsafat, Politik

\section{A. Pendahuluan}

Wacana tentang negara merupakan isu yang selalu menarik untuk diperbincangkan. Hal itu karena konsep atau bentuk sebuah negara akan menentukan corak kebijakan politik sebuah negara. Pada gilirannya konsep negara tersebut berdampak secara langsung terhadap kehidupan masyarakatnya. Dalam pandangan Weber, negara merupakan perwujudan historis sebuah kolektivitas sosial dalam memenuhi tuntutan harkat manusia pada sebuah negara. ${ }^{1}$ Dari sini dapat dipahami bahwa keberadaan suatu negara merupakan sistem pelaksanaan tata aturan yanag telah disepakati bersama oleh suatu kelompok masyarakat pada suatu wilayah tertentu.

Secara fungsional, negara merupakan institusi yang berupaya mengakomodir kepentingan individu dalam rangka mewujudkan kebahagiaan hidup. Dalam pelaksanaannya negara diberi kewenangan dan mandat untuk menata dan memelihara ketentraman masyarakat guna mewujudkan tujuan bersama. Dari sinilah kemudian Maskuri

1 Georges Balandier, Antropologi Politik, Terj. Y. Budi Sanstoso, (Yogyakarta: Rajawali Pers, 1986), h. 161. 
Abdullah menyimpulkan bahwa negara secara universal merupakan sistem penyelenggaraan pemerintahan dan sistem pengorganisasian masyarakat paling baik yang dibuat oleh manusia. ${ }^{2}$

Mengingat pentingnya keberadaan negara, telah banyak para ahli yang memberikan pemikirannya. Mulai dari zaman Yunani Klasik hingga dewasa ini. Dalam khazanah pemikiran Islam, AlFarabi merupakan salah satu sarjana yang memberikan perhatian tentang konsepsi politik kenegaraan. Meskipun sebelumnya sudah ada sarjana lain, seperti Ibnu al-Muqaffa (106-145 H/724-762 M), yang membicarakan soal-saol pemerintahan, dan Al-Kindi, the first Pihilosopher of Islam, yang menurut catatan M. Luthfi Jum'ah telah mengarang 12 buku mengenai politik. Namun demikian Al-Farabi dianggap sebagai sarjana muslim pertama yang memiliki konsep kenegaraan yang lengkap dengan konsepsi-konsepsi dan teori politiknya. Al-Farabi yang mengusung konsep al-madīnah al-fädilah dianggap sebagai perintis jalan dalam konsep kenegaraan. ${ }^{3}$

Dalam tulisannya tentang al-Madīnah al-Fāḍilah Al-Farabi berusaha mengharmonikan antara agama dan filsafat. Konsep kenegaraan yang terdapat dalam teori al-Farabi ini banyak mencontoh bentuk dan hakikat kepimpinan Rasullullah Saw sebagai seorang Rasul dan khalifah yang agung dimuka bumi ini. Sikap kepimpinan Rasullullah menjadi titik tolak kecenderungan al-Farabi dalam melahirkan pemikiran mengenai konsep kenegaraan. Pemikiran alFarabi ini penting dalam menyelesaikan kemelut masyarakat bagi mencari suatu bentuk negara yang ideal. Dengan adanya konsep negara yang di cetuskan oleh Al-Farabi, dimaksudkan agar terciptanya suatu pemahaman yang baik tentang bentuk negara yang sebenarnya yang di idam-idamkan al-Farabi

Berangkat dari paparan di atas, tulisan ini akan membahas tentang konsep negara ideal menurut al-Farabi dan relevansinya bagi kehidupan bernegara di Indonesia. Tulisan ini merupakan studi kepustakaan yang bersifat kualitatif dengan pendekatan deskriptif analisis.

${ }^{2}$ Maskuri Abdullah, Demokrasi di Persimpangan Makna: Respon Intelektual Muslim Indonesia Terhadap Demokrasi (Yogyakarta: Tiara Wacana, 1999), h.71.

${ }^{3}$ Lihat dalam H. Zainal Abidin Ahmad, Negara Utama, (al-Madianah alFadilah) (Jakarta: Kinta, 1968), 2. 


\section{B. Konsep Negara al-Farabi}

Pada bagian ini akan diketengahkan pemikiran Al-Farabi tentang negara. Dalam hal ini ada tiga hal pokok yang akan dikaji, yaitu karakteristik negara ideal, klasifikasi masyarakat, dan klasifikasi negara.

\section{Karakteristik Negara Utama}

Seperti halnya Plato, Aristoteles dan juga ibnu Abi Rabi' sebelumnya, al-Farabi berpendapat bahwa manusia adalah makhluk sosial, makhluk yang mempunyai kecenderungan alami untuk bermasyarakat, karena tidak mampu untuk memenuhi kebutuhan hidupnya sendiri tanpa bantuan atau kerja sama dengan orang lain. Adapun tujuan bermasyarakat, dalam pandangan al-Farabi, tidak semata-mata untuk memenuhi kebutuhan pokok hidup, tetapi juga untuk menghasilkan kelengkapan hidup yang akan memberikan kepada manusia kebahagiaan, tidak saja materiil tetapi juga sprituil, tidak saja didunia yang fana ini tetapi juga di akherat nanti. Pendapat al-Farabi tentang tujuan hidup bermasyarakat atau bernegara itu memperlihatkan pengaruh keyakinan agamanya sebagai seorang islam di samping pengaruh tradisi pemikiran Plato dan Aristoteles yang mengaitkan politik dengan moralitas, akhlak atau budi pekerti. Tujuan Al-Farabi di dalam Konsep (Al-Madinah Al-Fadilah). Pertama, Mencita-citakan akan mengatur dunia Internasional dengan satu lembaga yang bersifat Universal dan untuk mencontohkan suatu negara utama (al-Madinah al-Fädilah), seperti halnya pendapat Plato dan Aristoteles, yaitu suatu negara yang sempurna lagi cerdas dimana pemimpin negaranya dipimpin oleh seorang filosof yang suci jiwanya sehingga dapat mendekati sifat seorang Nabi. ${ }^{4}$ Kedua, Negara menurut al-Farabi, adalah suatu negara ketuhanan yang bertujuan kebahagian bersama, materil dan spritual dibawah pimpinan seorang Presiden dan atau bersama wakil-wakinya yang bersifat kenabian. Negara itu didukung oleh rakyatnya yang bersifat gotong royong, kolektif dan kooperatif di dalam cara berfikirnya dan cara bekerjanya.

Setiap negara yang dibangun harus mempunyai tujuan (ends of the state), yang menjadi cita-cita utama dan idaman oleh setiap warga negaranya. Al-Farabi menegaskan bahwa setiap warga negara harus mempunyai ide $\left(\operatorname{Ara} \bar{a}^{\prime \prime} u\right)$ yang harus diperjuangkan terus-

\footnotetext{
${ }^{4}$ Zainal, Negara, 103.
} 
menerus dan menuju kepada suatu titik yang terakhir dari negaranya, yang menjadi harapan dan tujuan bersama. Bagi al-Farabi tujuan terakhir itu ialah "kebahagian" (happiness). Adapun karakter negara utama dapat ditinjau dari beberapa dimensi, diantaranya:

\section{a. Ideologi Warga Negara}

Cita-cita Utama atau Negara Sempurna. Konsepnya tersebut diuraikan dalam buku yang berjudul "Arā" $u$ ahli Madīnah alFädilah" (The principle of the community of model City). Berdasarkan pendapatnya bahwa negara adalah berasal dari masyarakat kota. Membicarakan soal negara dimulailah dari manusia yang menjadikan warga negara tersebut dan yang membentuk masyarakat itu. Manusia atau warga mempunyai dasar fikiran dan pendapat yang mengharuskan dia bekerja dan berjuang mencapai tujuan negara yang terakhir ialah kebahagian.

Manusia yang berfikir dan bercita-cita yang dapat menjadi warga negara dari suatu negara, dan suatu negara utama hanya dapat didirikan oleh warga yang utama pula. Untuk menjadi warga negara yang utama tersebut manusia harus mempunyai kemauan bulat yang mendorongnya untuk bertindak baik, dimana perbuatn itu mendorongnya untuk bertindak baik maupun tindakan itu sudah dilakukan dalam bentuk perbuatan.

b. Akhlak

Mengenai akhak utama ini Al-Farabi membicarakannya di dalam buku yang komentarnya terhadap karangan Aristoteles yang dinamakannya Kitabu al- Akhlaq (Aristotle Nicomachaen ethics). Buku ini adalah buku pertama dalam bahasa arab mengenai ilmu akhlak. Sebagai perintis jalan ilmu tersebut Al-Farabi sudah meletakkan dasar-dasar yang kuat. Bukan saja ia menterjmahkan berbagai buku-buku dan pendapat Aristoteles, yang berdasarkan kepada filsafat semata, tetapi dibawahnya dasar baru yang lebih kuat ialah agama Islam, dan ia memberikan tujuan bahwa yang akhir dari akhlak adalah mencapai kebahagian total, kebahagian materil dan kebahagian spritual, akhlak dibaginya menjadi 2 bagian yaitu akhlak (Mahmudah) adalah akhlak yang baik dan akhlak (Mazmumah) adalah akhlak yang jahat.

Setiap warga negara yang utama melatih diri dan membiasakan sifat-sifat yang utama, sehingga menjadi karakter (tabi"at) yang baik baginya dan menjauhkan dirinya dari tiap-tiap 
perbuatan yang tercela dan tiap-tiap sifat yang rendah. Sesuai dengan syarat-syarat yang dikemukakannya bahwa setiap warga negara harus mempunyai ideologi, begitu juga warga itu harus mempunyai akhlak yang utama.

Dengan apakah akhlak yang utama itu dapat diketahui dan apakah ukurannya yang diapakai untuk menetapkan akhlak yang yang rendah (jahat). Aristoteles menjawabnya: ukurannya ialah fikiran (akal), dan falsafah. Dijaman sekarang ini bisa dijabarkan menjadi 5 dasar yaitu: theologis (agama), hedonis (rasa senang), utilistis (manfaat), vitalistis (kekuasaan), naturalistis (hukum alam), dan idealistis (cita-cita yang tinggi). ${ }^{5}$ Dari kecendrungan manusia untuk bermsyarakat, lahirlah berbagai macam masyarakat, di antaranya ada yang merupakan masyarakat-masyarakat yang sempurna, dan di antarannya ada yang tidak sempurna. ${ }^{6}$

\section{c. Keragaman}

Al-Farabi berkeinginan memperjuangkan perwujudan gagasan tentang persamaan dan persatuan antar manusia sebagaimana yang diperjuangkan oleh Plato sebelum- sebelumnya. Hanya saja, gagasan ini sulit untuk diwujudkan dikarenakan adanya perbedaan diantara bangsa-bangsa yang memiliki keragaman karena factorfaktor tertentu, diantaranya watak atau tabiat, adat istiadat, lingkungan alam sekitarnya dan bahasa karena setiap bangsa memiliki bahasa sendiri. Al-Farabi menegaskan, bangsa-bangsa memiliki keragaman karena dua factor alamiah, yaitu bentuk kejadian dan lingkunga alam, dan ditambah dengan factor lain di luar factor alamiah, yaitu bahasa

Perbedaan ini dipicu oleh oleh sebab-sebab alamiah pula, seperti perbedaan unsure langit yang membentuk sepiritual, perbedaan unsure bumi membentuk fisik, serta unsure geologis tempat tinggal. Perbedaan geologi akan berdampak pada perbedaan uap yang naik dari bumi. Setiap uap yang terjadi di bumi akan menjadi persoalan-persoalan tertentu bagi suatu wilayah. Perbedaan uap berdampak pada perbedaan udara dan air. Perbedaan udara dan air akan berdampak pada keragaman tumbuh-tumbuhan dan hewan. Dengan demikian, beragam pula makanan suatu bangsa. Keragaman

\footnotetext{
${ }^{5}$ Ibid.

${ }^{6}$ Ibid., 51
} 
makanan manusia diikuti keragaman material dan pertanian yang darinya manusia masa lalu terbentuk. Ini berdampak pada perbedaan tabiat. ${ }^{7}$ Dari pengaruh faktor lingkungan iklim, geografis dan makanan masyarakat setempat akan membntuk pola berpikir hubungan social masyarakat tertentu, dan selanjutnya akan mempengaru hubungan social, watak, tradisi yang mengakibatkan keragaman system sosail politik masyarakat tertentu.

2. Klasifikasi Masyarakat

a. Masyarakat Sempurna

Menurut al-Farabi ada tiga macam masyarakat yang sempurna; Pertama, masyarakat sempurna besar, yaitu gabungan banyak bangsa yang sepakat untuk bergabung, bantu membantu dan kerja sama. ${ }^{8}$ Kedua, masyarakat sedang, yaitu masyarakat yang terdiri dari satu bangsa yang menempati suatu teritorial (Negara). Ketiga, masayarakat kecil, yaitu masyarakat sempurna yang menempati dalam suatu Negara-Kota. ${ }^{9}$ Atau dengan nama lain yaitu; masyarakat sempurna besar adalah perserikatan bangsa-bangsa, masyarakat sempurna sedang adalah Negara nasional, sedangkan masyarakat sempurnah kecil adalah Negara-kota. ${ }^{10}$

\section{b. Masyarakat Tidak Sempurna.}

Sedangkan masyarakat-masyarakat yang belum atau tidak sempurna, menurut al-Farabi, adalah penghidupan social di tingkat desa, kampong, lorong dan dalam keluarga; diantara ketiga bentuk pergaulan yang tidak atau belum sempurna itu, maka kehidupan social di dalam rumah atau keluarga merupakan bentuk masyarakat yang paling tidak sempurna. Keluarga merupakan bagian dari masyarakat lorong, masyarakat lorong merupakan bagian dari masyarakat kampong, dan masyarakat kampong merupakan bagian dari masyarakat Negara-kota. Tebentuknya kampong dan desa, keduanya diperlukan oleh Negara-kota. Hanya bedanya, kampong merupakan bagian dari Negara-kota, sedangkan desa hanya merupakan pelengkap untuk melayani kebutuhan Negara-kota tersebut. Bisa dikatakan bahwa al-Farabi menganggap bahwa tiga unit

\footnotetext{
${ }^{7}$ Ali Abdul Mu'ti Muhammad, Filsafat Politik, 357.

${ }^{8}$ Muhammad Azhar, Filsafat Politik, 78.

${ }^{9}$ Ali Abdul Mu'ti Muhammad, Filsafat Politik, 354.

${ }^{10}$ Munawir Sjadzali, Islam dan Tata Negara, 51.
} 
pergaulan social masyarakat tersebut tidak merupakan masyarakatmasyarakat yang sempurna karena tidak cukup lengkap untuk swasembada dan mandiri dalam memenuhi kebutuhan para warganya, baik kebutuhan ekonomi, social, budaya dan sepiritual. ${ }^{11}$

\section{Klasifikasi Negara}

Al-Farabi mempunyai perhatian yang serius terhadap gagasan dunia secara keseluruhan. Al-Farabi berbicara tentang bangsa sebagai kumpulan dari sebuah kota, dan kota dinilainya sebagai masyarakat kecil yang sempurna. Ia mensyaratkan adanya elaborasi yang sempurna di kota, atau bangsa maupun dunia agar menghasilkan kebahagiaan secara hakiki dan menyandang gelar keutamaan. Menurutnya bahwa masyarakat yang berkolaborasi untuk memperoleh kebahagian adalah masyarakat yang utama. Bangsa yang kota-kotanya berkolaborasi untuk memperoleh kebahagiaan adalah bangsa yang utama. Dunia yang bangsa-bangsanya berkolaborasi untuk memperoleh kebahagiaan adalah dunia yang utama. ${ }^{12}$

Al-Farabi kemudian memfokuskan pada pembahasan pembagian Negara-kota ke dalam berbagai macam Negara/kota yakni antara lain:

\section{a. Kota Utama (al-madinah al-fadilah)}

Pemikiran A-Farabi tentang negara banyak dipengaruhi oleh konsep Plato yang menyamakan negara dengan anggota tubuh manusia. Kepala, tangan, kaki, dan anggota tubuh lainnya masingmasing memiliki fungsi tertentu. Menurutnya, bagian yang paling tinggi dalam tubuh manusia itu adalah kepala, karena kepala (otak), segala perbuatan manusia dikendalikan, sedangkan untuki mengndalikan kerja otak dilakukan oleh hati. ${ }^{13}$ Begitu juga sebuah Negara, al-Farabi mengibaratkan sebuah Negara-Kota bagaikan tubuh manusia yang sehat dan utuh yang selalu bekerja sama untuk kesempurnaan hidup dan kesehatannya. Tubuh manusia mempunyai sejumlah organ tubuh dengan berbagai fungsi yang berbeda satu dari yang lain. Dari organ yang banyak itu ada satu organ yang sangat penting atau utama, yakni jantung, dan beberapa organ lain yang tingkat kepentingannya bagi tubuh manusia hampir sama dengan

\footnotetext{
${ }^{11}$ Ibid., 52.

${ }^{12}$ Ibid., 358.

${ }^{13}$ Hayimsyah Nasution, Filsafat Islam (Jakarta: Gaya Media Pratama 2002), 
jantung, dan yang bekerja sesuai dengan kodrat masing-masing. Organ-organ ini, bersama jantung - dilihat dari sisi pentingnya menduduki peringkat pertama. Diluar itu terdapat sekelompok organ lain yang kerjanya membantu dan melayani organ-organ pendukun jantung. Organ-organ ini berada pada peringkat kedua. Kemudian, ada organ-organ lain yang tugasnya melayani organ-organ peringkat kedua tadi, dan demikian seterusnya sampai kepada anggota-anggota tubuh yang tudgasnya anggota-anggota tubuh lain yang tidak dilayani. ${ }^{14}$

Demikian pula dengan Negara-utama menurut al-Farabi, dimana Negara-utama mempunyai warga-warga dengan bakat dan kemampuan yang tidak sama antara satu dengan yang lain. Diantara mereka terdapat seorang kepala dan sejumlah warga yang martabatnya mendekati martabat kepala, dan masing-masing memiliki bakat dan keahlian untuk melaksanakan tugas-tugas yang mendukung kebijaksanaan kepala. Mereka ini, bersama-sama si kepala, teramasuk peringkat pertama. Di bawah mereka terdapat sekelompok warga yang tugasnya mengerjakan hal-hal yang membantu warga-warga tingkat pertama tadi, dan kelompok ini berada pada peringkat atau kelas dua. Kemudian dibawah mereka terdapat kelompok lain lagi yang bertugas membantu kelas yang di atasanya, dan terus demikian sampai kepada kelas terakhir dan terendah yang terdiri dari warga-warga yang tugasnya dalam Negarautama itu hanya melayani kelas-kelas yang lain, dan mereka sendiri tidak dilayani oleh siapa pun. ${ }^{15}$

Jika keragaman anggota tubuh terjadi berdasarkan alami, keragaman warga sebuah Negara-kota, walaupun keadaan mereka sesungguhnya bagian dari alami pula, prilaku yang mereka perbuat tidaklah alami, tetapi berdasarkan pilihan. Warga Negara-kota secara fitrah dikaruniai watak yang berbeda-beda, tetapi mereka menjadi bagian dari warga Negara-kota bukanlah atas dasar fitrah itu, tetapi karena pilihan-pilihan yang dihasilkan oleh, misalnya profesi.

Sebagaimana tubuh yang terdiri dari sejumlah anggotanya yang serasi, demikian pula negara-kota utama yang terdiri dari anggota-anggotanya yang saling menyatu, berkait, dan terikat. ${ }^{16}$

\footnotetext{
${ }^{14}$ Ali Abdul Mu'ti Muhammad, Filsafat Politik, 359.

${ }^{15}$ Munawir Sjadzali, Islam dan Tata Negara, 53.

${ }^{16}$ Ali Abdul Mu’ti Muhammad, Filsafat Politik, 360.
} 
Menurut Harun Nasution dalam bukunya, bahwa pekerjaan yang terpenting dalam masyarakat adalah pekerjaan kepala masyarakat/Negara-kota. Kepala sumber dari segala peraturan dan keharmonisan dalam masyarakat/Negara-kota. Ia mesti bertubuh sehat dan kuat, pintar, cintah pada ilmu pengetahuan dan pada keadilan. Ia harus telah mempunyai akal dalam tingkat ketiga, akal mustafad (acquired intellect) yang telah dapat berkomunikasi dengan Akal Kesepuluh, pengatur bumi kita ini. Sebaik-baik kepala ialah Nabi atau Rasul. Kepala yang serupa inilah yang dapat mengadakan peraturan-peraturan yang baik dan dapat berfaedah bagi masyarakat, sehingga masyarakat menjadi makmur dan baik dan dalamnya anggota-anggota dapat memperoleh kesenangan. Tugas kepala Negara, bukan hanya mengatur Negara tetapi mendidik manusia mempunyai akhlak yang baik. Kalau sifat-sifat yang dekat menyerupai sifat-sifat Nabi/rosul tak terdapat pada salah satu orang, tetapi dalam diri beberapa orang, maka Negara diserahkan kepada mereka dan di antara mereka mesti ada yang mempunyai sifat filosof, adil dan sebagainya. ${ }^{17}$

Sejalan dengan hal itu, al-Farabi berpendapat bahwa tidak setiap warga mampu dan dapat menjadi pemimpin Negara/kota. Yang boleh menjadi pemimpin Negara-utama hanyalah manusia yang paling sempurna. Al-Farabi berkata, "Sebagaimana organ pokok tubuh, secara alami, adalah yang paling sempurna, demikian pula pemimpin Negara-utama harus berupa orang yang paling sempurna.

Pemimpin Negara-utama harus dipegang oleh seseorang yang memiliki dua hal, yaitu (1) fitrah dan tabiat, (2) talenta dan kehendak. Al-farabi menegaskan bahwa pemimpin Negara-utama tidak tidak bisa dijabat oleh sembarang orang, tetapi bagi orang yang memiliki dua hal tersebut diatas. ${ }^{18}$

Adapun karakter atau criteria seorang kepala Negara-utama harus memenuhi kualitas luhur, yaitu: 1) Lengkap anggota badannya; 2) Baik inteligensinya dan mudah dimengerti; 3) Mutu intelektualitasnya; 4) Pandai mengemukahkan pendapatnya dan mudah dimengerti; 5) Pecinta pendidikan dan dan gemar mengajar; 6) Tidak loba dalam hal makanan, minuman, maupun wanita; 7)

\footnotetext{
${ }^{17}$ Harun Nasution, Filsafat dan Mitisisme, 32-33.

${ }^{18}$ Ali Abdul Mu’ti Muhammad, Filsafat Politik, 360.
} 
Mencintai kejujuran dan kebenaran; 8) Berbudi luhur; 9) Tidak mengutamakan keduniaan; 10) Bersifat adil; 11) Optimisme dan besar hati; dan 12) Kuat pendirian, penuh keberanian, antusiasme dan tidak berjiwa kerdil. Andaikata tidak ada seorangpun yang memenuhi dua belas karakter itu, kepala Negara dapat dipikul secara presidium. ${ }^{19}$

Semua karakter di atas memang sukar dilialisir dan jarang bisa dtemukan dalam kepribadian seseorang, sebagiamana diakui sendiri oleh al-Farabi. Sungguhpun demikian, ia justru menambahkan satu karakter yang bercorak sufistik, ialah pemimpin Negara yang harus mampu naik pada dataran akal fa'al (akal aktif) yang darinya wahyu dan ilham dapat diambil. ${ }^{20}$

\section{b. Negara Bodoh (al-madinah al-jahiliyyah)}

Sebagaimana kebalikannya dari Negara yang utama terdapat Negara yang bodoh, Negara yang rusak, negara yang merosot, dan negara yang sesat. Negara yang bodoh adalah negara yang rakyatnya tidak tahu tentang kebahagiaan dan tidka terbayang pada mereka apa kebahagiaan itu. Kalau di tuntun mereka tidak mau mengikuti dan kalau diberi tahu mereka tidak mau percaya. ${ }^{21}$ Mereka tidak mengenal, kecuali kebaikan inderawi sebagaimana yang dinikmati binatang. Mereka hanya memerlihatkan kenikmatan tubuh, kemudahan, dan kelezatan. Al-Farabi membagi negara bodoh menjadi enam macam:

1) Negara primitif, yaitu negara yang penduduknya hanya memerhatikan pemenuhan kebutuhan pokok hidup, seperti makan, minum, pakaian, tempat tinggal, dan jodoh serta kerja sama untuk pengadaan keperluan tersebut.

2) Negara hedonis, yaitu negara yang penduduknya mementingkan penumpukan kekayaan dan kemudahan-kemudahan materi. Mereka menjadikan materi sebagai tujuan utamannya.

3) Negara hina dan sakit, yaitu negara yang penduduknya hanya mementingkan kenikmatan makanan, minuman, seks, dan berbagai hiburan lainnya.

\footnotetext{
${ }^{19}$ Muhammad Azhar, Filsafat Politik, 79.

${ }^{20}$ Ibid.

${ }^{21}$ Munawir Sjadzali, Islam dan Tata Negara, 57.
} 
4) Negara penghormatan, yaitu negara yang penduduknya hanya mementingkan kehormatan saja karena berorientasi pada gengsi atau kehormatan public, dinamakan negara ningrat atau timokrasi

5) Negara tirani atau desponis, yaitu negara yang di dalamnya penaklukan atau dominasi menjadi dambaan para penduduknya. Mereka terus berusaha mengalahkan dan menjajah orang lain demi sebuah kekuasaan.

6) Negara anarkis atau demokratis, yaitu negara yang setiap penduduknya ingin merdeka melakukan keinginannya masingmasing karena kebebasan individual menjadi tujuan utama meskipun berujung pada pelanggaran hokum dan anarkis. ${ }^{22}$

\section{c. Negara Rusak (al-madinah al-fasiqah)}

Adapun negara rusak, yaitu negara yang rakyatnya tahu apa kebahagiaan itu, sama halnya dengan rakyat di negara yang utama, tetapi mereka berprilaku dan hidup seperti rakyat di negara yang bodoh. Dengan kata lain, mereka tahu tentang hal-hal yang baik, tetapi yang mereka lakukan adalah perbuatan yang hina. ${ }^{23}$

\section{d. Negara yang Merosot (al-madinah al-mubaddilah)}

Negara merosot adalah negara yang pandangan-pandangan dan perbuatan-perbuatan penduduknya pada mulanya sama dengan pandangan dan perbuatan masyarakat negara utama, kemudian beralih dan pandangan itu karena kemasukan pandangan lain sehingga terjerumus kedalam pandangan yang tidak terpuji. ${ }^{24}$

\section{e. Negara Sesat (al-madinah adh-dalalah)}

Negara yang sesat adalah negara yang diliputi oleh kesesatan, penipuan dan kesombongan. Rakyatnya tidak percaya akan adanya Tuhan, dan sebaliknya kepala negara menipu rakyatnya dengan pengakuan bahwa dia menerima wahyu dari Tuhan, dan bahwa rakyat harus ikut apa yang dikatakan dan lakukannya sebagaimana mereka

\footnotetext{
${ }^{22}$ Ali Abdul Mu'ti Muhammad, Filsafat Politik, 362.

${ }^{23}$ Munawir Sjadzali, Islam dan Tata Negara, 57.

${ }^{24}$ Abu Nasr al-Farabi, Ara' Ahl al-Madinah al-Fadilah (Bairut: Da al-Iraq,
} 2002), 133. 
harus mengikuti apa yang dikatakan dan dilakukan oleh seorang nabi. $^{25}$

\section{f. Rumput-rumput Liar (nawabit)}

Lawan negara yang utama bukan hanya negara-negara yang bodoh dan sebagainya tadi. Tidak kurang bahayanya adalah "rumputrumput liar/jahat" yang mungkin terdapat dalam tubuh negara yang utama sekalipun. Yang dimaksudkan denga rumput-rumput liar itu ialah orang-orang atau unsure-unsur yang rendah budi pekertinya, manusia berwatak liar dan tanpa budaya, yang dapat mengganggu keserasian kehidupan masyarakat di negara yang utamapun. ${ }^{26}$ Nawabit ini menyerupai dengan duri yang tumbuh dan menghisap pada keringat orang lain dan tidak member manfaat apa-apa. Mereka yang dikatagorikan ke dalamnya menyerupai binantang dalam perlakuannya. Seakan-akan masyarakat rumput liar ini bagaikan komunitas kejahatan yang diliputi kezaliman, pembunuhan, perampokan, dan pencurian. Mereka hidup dengan menghisap darah orang lain. ${ }^{27}$

\section{Relevansi Konsep Al-Farabi Terhadap Kehidupan Bernegara di Indonesia}

Membentuk atau mendirikan suatu negara atau pemerintahan untuk mengelola urusan rakyat (ummat) merupakan kewajiban agama yang paling agung karena agama tidak mungkin tegak tanpa negara dan pemerintahan. Ukuran tegaknya suatu nilai-nilai agama seperti keadilan, keamanan ketertiban dan keadaban hanya bisa dilakukan melalui negara dan pemerintahan. ${ }^{28}$

Islam bukan hanya semata-mata mengajarkan agama, akan tetapi juga mengatur masalah-masalah negara, masalah politik dan lain-lain yang berkaitan dengan kebaikan hidup di dunia dan akhirat. Bila kita tinjau secara sistematis, agama Islam mengajarkan tentang masalah-masalah kenegaraan, antara lain:

\footnotetext{
${ }^{25}$ Munawir Sjadzali, Islam dan Tata Negara, 58.

${ }^{26}$ Ibid.

${ }^{27}$ Ali Abdul Mu’ti Muhammad, Filsafat Politik, 364.

${ }^{28}$ Syamsudin Haris, Demokrasi di Indonesia, Gagasan dan Pengalaman
} (Jakarta: LP3S, 1995), 5. 
1. Di dalam ajaran Islam ditemui prinsip-prinsip musyawarah, pertanggung jawaban pemerintahan, kewajiban taat kepada pemerintahan dalam hal-hala yang berkaitan dengan makruf, hukum -hukum di dalam keadan perang dan dalai, perjanjian antar negara. Dalam sunnah Nabi SAW sering kita temukan kata-kata amir, iman yang menunjukkan kepada kekuasaan dan pemerintahan.

2. Negara penting sekali di dalam rangka melaksanakan hukumhukum Islam. Bahkan sebahagian hukum Islam tidak dapat dilaksanakan tanpa adanya negara seperti hukum pidana.

3. Di kalangan fuqaha kita kenal istilah darul al-Islam dan daru alharb. Darul Islam sesunggguhnya adalah Daulah Islamiyyah.

4. Sejarah berbicara kepada kita bahwa Nabi SAW juga seorang kepala negara ketika beliau berada di Madinah.

Keingian semua orang di dunia ini ingin hidup dalam sebuah negara yang aman, damai, dan makmur. Tentunya kita semua ingin hidup dalam sebuah negara yang mana rakyat benar-benar selalu diperhatikan dan disayangi oleh pemimpinnya. Kita juga ingin tinggal dalam sebuah masyarakat yang menghargai hak-hak individu dan harga diri serta martabat anggotanya. Kita semua bisa beraktivitas dalam masyarakat yang bahagia, bukan masyarakat yang mengalami kelemahan fisik ataupun sakit. Singkat kata kita ingin tinggal, hidup, dan beraktivitas, menjadi bagian dari masyarakat yang utama, bukan masyarakat yang sesat ataupun rusak. Untuk bisa mencapai hidup di dalam tipe masyarakat yang ideal/ utama seperti itu tidaklah mudah.

Umat Islam sebagai bagian terbesar dari bangsa Indonesia harus menjadi kekuatan moral yang mengingatkan para pemimpin bangsa. Sudah saatnya paradigma/pola fikir pembangunan diubah. Pertumbuhan ekonomi memang baik namun bukan satu-satunya indikator kemajuan bangsa. Kehidupan keberagamaan bangsa Indonesia berada pada titik kritis. Kelompok-kelompok tertentu yang menafsirkan agama secara tekstual berusaha meneror kelompokkelompok masyarakat yang lain. Keberagamaan bangsa Indonesia nyaris terancam oleh kelompok-kelompok radikal. Pada titik ini, agama bukan memberikan solusi malahan menjadi bagian dari masalah. Agama kian jauh dari kearifan dan lebih banyak disandingkan dengan kekerasan dan kekakuan cara berpikir. Pemikiran politik Al-Farabi mengenai tujuan politik sangat penting 
untuk dicamkan oleh para elit politik Indonesia, dan lebih baik lagi untuk semua kalangan yang mencintai negara Indonesia, guna menjadi negara yang baik sesuai dengan ajaran Islam. Oleh karena itu agama menjadi penting sebagai benteng moral. Tanpa agama, kehidupan masyarakat menjadi anarkis. Seperti yang tertuang di dalam Panca Sila yang pertama: Ketuhanan yang Maha Esa.

Sangat penting untuk diingat dan dipahami bahwa dalam penelitian ini, Al-Farabi berada di masa atau situasi kekacauan politik yang tidak pasti arah pembangunannya. Begitu juga masyarakat Indonesia pun kini mengalami hal yang serupa. Politik harus diisi oleh para moralis. Bukan para oportunis. Sehingga negara Indonesia memiliki jati diri sebagai negara yang besar dan yang dapat menjaga rakyatnmya aman, terntram dan sejahtera, dan tentunya seluruh umat Islam diIndonesia mengharapkan negara yang baik Baldatun Tayyiban dan rakyatnya saling bekerja sama dengan pemimpinnya.

\section{Penutup}

Al-Farabi yang merupakan ahli filsafat Islam mengemukakan teori al-Madīnah al-Fädilah untuk mengharmonikan antara agama dan filsafat. Konsep kenegaraan yang terdapat dalam teori al-Farabi ini banyak mencontoh bentuk dan hakikat kepimpinan Rasullullah Saw sebagai seorang Rasul dan khalifah yang agung dimuka bumi ini. Disamping itu juga pemikiran al-Farabi tentang negara utama tersebut banyak deipengaruhi oleh filosof yunani, di antaranya pemikrian Plato dan Aristoteles. Ini bisa terlihat seperti dalam pembagian tiga macam masyarakat sempurna dalam gagasan al-Farabi, yaitu masyarakat sempurna besar, sedang dan kecil. sebagaimana juga sama dengan pendapat kedua filosof dari yunani Plato dan Aristoteles, bahwa masyarakat sempurna kecil merupakan gambaran negara yang ideal. [.]

\section{Daftar Rujukan}

Abdillah, Maskuri, Demokrasi di Persimpangan Makna: Respon Intelektual Muslim Indonesia Terhadap Demokrasi, Yogyakarta: Tiara Wacana, 1999. 
Ahmad, H. Zainal Abidin, Negara Utama, (al-Madianah al-Fadilah), Jakarta: Kinta, 1968.

al-Farabi, Abu Nasr, Ara' Ahl al-Madinah al-Fadilah, Bairut: Da alIraq, 2002.

Azhar, Muhammad, Filsafat Politik: Perbandingan antara Islam dan Barat, Jakarta: Raja Grafindo Persada, 1997.

Balandier, Georges Antropologi Politik, Terj. Y. Budi Sanstoso, Yogyakarta: Rajawali Pers, 1986.

Haris, Syamsudin, Demokrasi di Indonesia, Gagasan dan Pengalaman, Jakarta: LP3S, 1995.

Muhammad, Ali Abdul Mu'ti, Filsafat Politik Antara Barat dan Islam, terj. Rosihon Anwar, Bandung: CV. Pustaka Setia. 2010.

Nasution, Harun, Falsafat dan Mistisisme dalam Islam, Jakarta: Bulan Bintang, 1995.

Nasution, Hayimsyah, Filsafat Islam, Jakarta: Gaya Media Pratama 2002.

Sjadzali, Munawir, Islam dan Tata Negara; Ajaran, Sejarah dan Pemikiran, (Jakarta: Universitas Indonesia Press, 1990) 